\section{Pesticide use in Brazil and problems for public health}

\author{
Uso de agrotóxicos no Brasil e problemas para \\ a saúde pública
}

\author{
Uso de pesticidas en Brasil y los problemas para \\ la salud pública
}

1 Centro de Ciências da

Saúde, Universidade Federal do Ceará, Fortaleza, Brasil.

\section{Correspondence}

R. M. Rigotto

Departamento de Saúde

Comunitária, Centro

de Ciências da Saúde,

Universidade Federal do

Ceará.

Rua Prof. Costa Mendes 1608,

5o andar, Fortaleza,

CE 60431-970, Brasil.

raquelrigotto@gmail.com
Pesticides are currently a major public health problem, considering the size of the exposed population in pesticide plants and surrounding areas, in farming, in fighting endemics and other sectors, in the vicinity of farming areas, and ultimately all of us, who are consumers of contaminated products. Between 2007 and 2011, according to data from the Information System of Compulsory Notification Conditions (SINAN), there was an increase of $67.4 \%$ of new non-fatal labor accidents due to pesticides, and the coefficient of intoxications had an overall increase of $126.8 \%$, and was even higher among women (178\%) 1. However, underdiagnosis and under-notification are widely acknowledged for acute cases - the limitation is even higher when it comes to the assessment of the chronic effects of pesticides -, which is explained by the gradual increase in consumption and intensification of use of such substances in Brazil.

The Brazilian pesticide market experienced a rapid expansion over the last decade (190\%), at a pace of growth more than double that of the global market (93\%), placing Brazil at the top of the world rank, since 2008. According to the Brazilian National Health Surveillance Agency (ANVISA) 2, for the 2010/2011 harvest, 936,000 tons were used, involving financial transactions of US\$ 8.5 billion among ten companies that control $75 \%$ of the market in the country. The permission for the
Raquel Maria Rigotto 1

Dayse Paixão e Vasconcelos 1

Mayara Melo Rocha 1

use of transgenic seeds in crops, and their dissemination in farming areas are associated with increase in consumption, taking into account the intensive use of herbicides, accountable for $45 \%$ of the volume used, followed by fungicides (14\%), and insecticides (12\%).

The results of the Food Pesticide Residues Analysis Program, developed by ANVISA, show that in 2011 only $22 \%$ of the 1,628 samples analysed were free from these contaminants. Attention is drawn to the presence of at least two pesticides that have never been registered in Brazil, azaconazole and tebufenpyrad, which suggest product smuggling 2 and lack of control of public policies.

The management of water contamination for human use by the health surveillance system, regulated by Ordinance n. 2,914/2011 is limited to cities of the Southern and Southeastern regions of Brazil, which does not allow for the situation in the whole of the country to be known ${ }^{3}$.

When considering the perspectives of future scenarios in relation to the use of pesticides in Brazil, one must look into the social disputes that exist, in which agents struggle for distinct, often contradictory, projects and interests, including ethical values that guide them.

On one hand, there are the social agents committed to the modernization of farming, according to the current trend of the interna- 
tional division of labor advocated by the major economic corporations, forcing Brazil and other Latin American and African countries towards a re-primarization of their economies and focus on the production of commodities. In this field, there are oligopolies of the chemical, metal-mechanics, and seed industries; big land owners, and an important participation of the financial sector. Supported by their economic and political power, they foster strong ties with powerful segments of the State - executive, legislative, and judiciary branches - to exert influence in the sway of development policies, in the destination of public loans for agro-industrial complexes, in legislation de-regulation and flexibility.

Science and technology policies and the training of human resources are also strongly influenced by these players, as exemplified by research studies carried out by Embrapa, and the focus given at agricultural science courses in universities, or at federal education institutes. In addition, they still count on mass media to disseminate the ideas of the "Green Revolution", which focus on the output increase of extensive singlecrop farming, mechanization, unavoidability of using chemical fertilizers and pesticides, expanding the market even in family farming.

This farming model has led to the emergence of super-plagues, causing massive economic losses, pressures for allowing the imports of pesticides forbidden in the country, and the thwarting of the current Brazilian legislation on pesticide use. The Parliamentary Crop-Livestock Framing and the Brazilian Agriculture and Livestock Confederation (CNA) are acting powerfully and in coordination on instrumental issues, such as territorial rights of Indians and slavedescendants (PEC 215/2000), land reform, forests, water, minerals, biodiversity, right to work and to health 4 .

Law n. 12,873/13 and Decree n. 8,133/13, are clear in regulating the permission for importing, manufacturing, marketing and use of pesticides in case of fitossanitary and zoosanitary emergencies, to be granted only by the Ministry of Agriculture, Livestock and Supplies (MAPA), waiving the assessment by health, and environment bodies. Currently being discussed in the Senate is PLS 209/2013, that establishes that a single body will be in charge of assessing pesticides, similarly to the procedures regarding transgenic seeds at the National Technical Committee on Biosafety (CTNBio) that has never refused a request made by the industry.

Another element that helps design future scenarios concerning the model of development and its implication on public health are the MAPA 2020/2021 estimates 5 that project an increase in the production of commodities for exports of $55 \%$ for soy beans, $56.46 \%$ for corn, and $45.8 \%$ for sugar, compared to 2011 . As these are chemical-dependent single-crop farming, the current contamination trends should deepen and expand.

On the other hand, this model causes impacts that are perceived by segments of the Brazilian society that do not sit still. The Permanent Campaign Against Pesticides and For Life currently brings together more than one hundred social organizations, and since 2011 it has been developing communications, training, and political connection actions, disclosing the problem and expanding the discussions; such was the intention, for instance, of the production and dissemination of videos like Silvio Tendler's O Veneno Está na Mesa I and II (The Poison is at the Table $I$ and $I I$ ).

The Abrasco Report 6 makes public the commitment of public health professionals in making available for society the scientific evidence of agrochemical hazards, with significant impact in the academic milieu, in the media and among social movements.

The concern and indignation originated in this process led to the following question: is there another way for agriculture and the production of food? It is aligned with the ideas of the International Peasants' Movement Via Campesina that designed a food sovereignty proposition that resonates in the discussions on food and nutrition safety held at the Food Safety National Council (CONSEA), leading to a striking document sent to President Dilma Rousseff 7, and the National Forum for Fighting Pesticide Effects, among other recipients.

This setting also fosters the development of the agroecologic field, particularly reflected in the National Articulation of Agroecology (ANA) and in the Brazilian Association of Agroecology (ABA): "Over the past few years, the expansion of the agroecological experience, the consolidation of successful cases in which the principles of agroecology were applied in all regions of Brazil, the systematizations showing the positive impact and the multifunctionality of agroecology, the struggle to ascertain the ways of life and of production of traditional populations provided a fertile ground for a strategy that gave more public visibility of agroecology to other segments of society, particularly in urban areas. [...] Agroecology is more clearly seen in the agenda of social peasants' movements, and was highlighted in the Unitary Meeting of Workers and People of the Country, the Waters and Forests" 4 (p. 4).

These groups organized, in May 2014, the III National Meeting of Agroecology, which gath- 
ered more than 2,000 farmers, experts and researchers, played a major role in the approval of Decree n. 7,794/2012 that established the National Policy of Agroecology and Organic Farming, and they remain organized to pressure and to collaborate with different sections of the government accountable for the implementation of the National Plan of Agroecology and Organic Farming (Planapo), which includes a National Plan to Reduce Pesticide Use. Abrasco has a seat at the National Committee that establishes the guidelines and monitors the implementation of the Plan (CNAPO), and also in the Work Group that will plan the reduction of pesticide use.

These facts indicate that discussions between the different perspectives on pesticide use will be stirred up, in a deeply asymmetrical dispute, considering the economic, political, and production might of those who intend to move towards a hegemonic development project. However, distinct forces are gathering up, advocating caution and health promotion, thus contributing to new perspectives for the future. Aligned with these ideas, the critical stand of researchers, professors, and health practitioners may positively help in the course to be taken.

\section{Contributors}

All authors participated in all stages of the article's production.
1. Centro Colaborador de Vigilância em Acidentes de Trabalho, Universidade Federal da Bahia. Acidentes de trabalho devido à intoxicação por agrotóxicos entre trabalhadores da agropecuária 20002011. Salvador: Centro Colaborador de Vigilância em Acidentes de Trabalho, Universidade Federal da Bahia; 2012.

2. Agência Nacional de Vigilância Sanitária. Programa de Análise de Resíduos de Agrotóxicos em Alimentos (PARA). Relatório de Atividades de 2011 e 2012. Brasília: Agência Nacional de Vigilância Sanitária; 2013

3. Secretaria de Vigilância em Saúde, Ministério da Saúde. Boletim Epidemiológico 2013; 44(10).

4. Monteiro D. Alguns elementos do contexto político no Brasil relacionado à agricultura e ao desenvolvimento rural. Rio de Janeiro: Articulação Nacional de Agroecologia; 2013.

5. Ministério da Agricultura, Pecuária e Abastecimento. Brasil: projeções do agronegócio 2010/2011 a 2020/2021. Brasília: Ministério da Agricultura, Pecuária e Abastecimento; 2011.

6. Carneiro FF, Pignati W, Rigotto RM, Augusto LGS, Rizollo A, Muller NM, et al. Dossiê ABRASCO. Um alerta sobre os impactos dos agrotóxicos na saúde. Parte 1 - Agrotóxicos, Segurança Alimentar e Saúde. Rio de Janeiro: ABRASCO; 2012.

7. Conselho Nacional de Segurança Alimentar e Nutricional. Carta à Presidente Dilma Rousseff. Brasília: Conselho Nacional de Segurança Alimentar e Nutricional; 2013. (E.M. no 003-2013/CONSEA).

Submitted on 14/May/2014

Approved on 15/May/2014 